\title{
An Analysis of Cthulhu Mythos' Influences in Modern Western Spine-chillers
}

\author{
Zhang Zhongjing ${ }^{1}$, Tian Chuanmao ${ }^{2}$
}

School of Foreign Studies, Yangtze University, Hubei, 434023 PRC China

Received: 5 Oct 2020; Received in revised form: 14 Nov 2020; Accepted: 16 Nov 2020; Available online: 19 Nov 2020

(C2020 The Author(s). Published by Infogain Publication. This is an open access article under the CC BY license

(https://creativecommons.org/licenses/by/4.0/).

\begin{abstract}
Cthulhu mythos is the general name of a series of horror novels represented by a horror writer who named Howard Phillips Lovecraft. This artificial mythological system provides a new content for horror novels, using special images to promote the plot and to set off the atmosphere to bring readers a new horrible feeling. Although when Lovecraft was alive, readers not paid attention to his works, but in the 21 th century, with the rapid development of technology and the Internet, more and more people are addicted in this strange world. Moreover, not only writers, but also video, game, animation and other fields have creators involved in it, showing the charm of Cthulhu Mythos. This paper mainly discusses the influence of the gruesome elements in Cthulhu Mythos on modern western Spine-chillers.
\end{abstract}

Keywords-Howard Phillips Lovecraft, Cthulhu Mythos, Modern Western Spine-chillers.

\section{INTRODUCTION}

As one of the important type of popular literature, horror fiction pays more attention to the content and theme on the feeling of terror than other kind of literatures. To this kind of fictions, Xiong Xin and Song Dengke had provided their definition:

Horror novels cause the reader to feel afraid, frightened, or disgusted by guiding the emotion of terror or fear. The subtlety of horror novels is that people are immersed in a scene, shocked by some kind of foreign body or pressure, forget time and all trifles, and completely immerse themselves in the atmosphere created by terror. Stimulate the reader's psychological and physical fear response. Horror novels may not be suitable for everyone, but this does not affect its strong literary and aesthetic appeal. (224)
Most critics thought that western horror literature consisted of gothic fictions and modern horror novels Although the horror fiction is a kind of preference which belongs to a small group of people, but the desire of writers to describe the horror feeling promoted them to add gruesome elements into their works.

When people used to talk about gothic fictions, the prominent masters, who were as influencing as Edgar Allan Poe, come to their mind. However, today those outstanding writers are deemed the representatives of an outdate fiction style by the young people, and their works can hardly stimulate the sensory feelings of the youth any more. Under this circumstance, a new artificial mythology system catch the people's eyes - it called Cthulhu Mythos, which was created by Howard Phillips Lovecraft in the last century. Unfortunately Lovecraft had a few readers when he was alive, and he did not have some reputation until he died. After H P Lovecraft passed away, August William Derleth, an important person to the whole Cthulhu Mythos, had 
collected Lovecraft's whole works about Cthulhu Mythos and published them. Then he also helped to accomplish a complete world system of Cthulhu Mythos. In a word, H P Lovecraft is the father of Cthulhu Mythos, and August helps to promote more and more people to know it.

Actually, H P Lovecraft was seemed to be one of the most influencing horror fiction writers in the 20th century. Innumerable modern writers learn from Cthulhu Mythos, and it continued attract new writers to join the creating group. Stephen Edwin King once referred H P Lovecraft as the most grand classical horror fiction author of the 20th century. From his work The Shinning, we can see the influences from Cthulhu Mythos - the whole peak hotel was a closed-inferno, for whoever in this hotel finally became insane. As a breakthrough, H P Lovecraft's works are much different from traditional gothic fictions.

Today, people can not only find the gruesome elements of Cthulhu Mythos from literature, but also can find them from modern films and television programs, even popular computer games. The gruesome elements of Cthulhu Mythos has integrated into western spine-chillers, exhibited a new horror system to people around the world.

And there are various kinds of aspects to study Cthulhu Mythos, but this paper chooses the relationship between the gruesome elements of Cthulhu Mythos in modern western spine-chillers. The 21th century has witnessed the growth of the Internet, meanwhile horror programs are becoming general things among the people, especially the young fellows. They are unsatisfied with the conventional stimulation, and furthermore, they have an appetite for the deepest dread inside them -- Cthulhu Mythos open a fresh door to them. It seems that a large number of programs make great use of the gruesome elements of Cthulhu Mythos, like Aquaman,The Shining, and so on. It's essential and diverting to find the relationship among the gruesome elements of Cthulhu Mythos in modern western spine-chillers, and it will help people to know better how H. P. Lovecraft and his work influence modern programs then to understand better what is Lovecraft's fictions and modern culture.

\section{LITERATURE REVIEW}

\subsection{An introduction of Cthulhu Mythos}

\subsubsection{Life of the author}

In 1890, Howard Phillips Lovecraft was born in to a wealthy family in Rhode Island. His father accumulated considerable wealth for jewelry and mineral business, and his mother also had a dignified birth. But something unexpected happened anytime. His father was certified and sent to the mental hospital when Lovecraft was three. From then on, he did not meet his father until his father passed away. Furthermore, Lovecraft had no choice but to recuperate at home for his chronic psychiatric illness when he was nine. The misfortune came one after another, his family members were trapped in the poverty since his grandfather left. They had to move out of the old residences, huddled in an entirely different and uncomfortable house. Lovecraft was extremely impressed by losing his family and his mental illness afflicted him at any moment. Causing physical and mental suffering, he failed to graduate from high school or get a permission of Brown University, even his marriage finally came to nothing.

As Kong Xiaoyi mentioned in the paper, Lovecraft's life experience had a great influence in his works: "The checkered experience and mental illness not only helped to improve Lovecraft's personality, but also helped him to contact with the world of fantasy literature, which led Lovecraft to write horrible fiction without hesitation .’(80)

Not only Kong Xiaoyi thought Lovecraft's life related to his works, but also Carter Lin and Joseph A Lesny also gave the agreements:

During H.P. Lovecraft's lifetime, his published works include one hundred and one short stories and forty-five poems that can break down into two literary themes: the cosmic horror of his Cthulhu Mythos and his Dreamland Epics inspired by the folklore of Lord Dunsany. (15)

Lovecraft's style of fiction brought new literary themes to the horror genre. Cosmic fear takes the place of the supernatural and mystical. The description of the physical 
atmosphere immerses the reader in such detail that the visuals set the suspenseful tone before any action is taken. (18)

\subsubsection{Definition of Cthulhu Mythos}

Cthulhu Mythos is a generic terms of the programs which used Cthulhu gruesome elements or images. It was a new-born artificial mythic system, a mythic system collected a number of writers' works and based on American writer H P Lovecraft's fictions, put in shape by August William Derleth . Lovecraft did not finish this system until he died, he tried to reveal a universe without order just full of chaos, but his world view was substituted by Derleth's mind. Derleth put his Christian value into Cthulhu Mythos, and add a new concept - Elder Gods - into the system.

Because of the ups and downs of his life, Lovecraft's works are full of doubts and pessimism contrary to the spirit of the times. The understanding of the small existence of human beings and the perception of the unknown universe are the two main lines that run through the beginning and end of Lovecraft's novels. They also achieve the common theme of Lovecraft's novels: human is meaningless in the universe, and all the exploration of the mysterious unknown will lead to the end of disaster. Humans often rely on the forces of other powerful beings in the universe, but these beings have no interest, if not malice, in humans.

As opposed to small human beings, there are endless unknown, powerful and terrifying evil gods. These old dominators, who existed long before the birth of mankind, crossed the universe into the young world, but now they are far away from human beings and live in the depths of the earth and the ocean. The most famous of these old dominators is Cthulhu, who sleeps in the undersea city of R'lyeh in the South Pacific. When the great evil god Cthulhu wakes up from the powerful undersea city of R'lyeh, he becomes the strongest being, and the whole world will be back under his control. When the houses of the stars are arranged in a certain order, Cthulhu will return to the world. Although Cthulhu is so famous that the entire legend system is named after it, it is not the most powerful in this story system, nor is it the center of the story. It belongs to the core part of Cthulhu Mythos - Great Old Ones, an ancient horror force which controls evil power. ISSN: 2456-7620
Actually at the center of the system is Azathoth, the head of Outer Gods. And Nyarlathotep, who comes into contact with the human world more frequently and prefers to deceive and seduce humans than other Outer Gods. At the beginning of the birth of the universe, only Azathoth existed, from Azathoth came "darkness", "nameless fog" and "chaos". The blind and foolish Azathoth first gave birth to "darkness," and "darkness" gave birth to the "supreme mother god," Shub-Niggurath, who had a strong fertility. It is said that she gave birth to almost all Great Old Ones, including Cthulhu, and even all life. "Nameless fog" produced the "key to the door" Yog-Sothoth, knowing all the time and space, is the existence of the silver door key. Chaos, often referred to as the messenger, is the symbol of ridicule and contradiction.

In addition to the old dominators who existed in the name of God, some sci-fi intelligent alien creatures also accounted for a number of articles, such as Mi-Go in The Whisperer in Darkness. And Kelabu mentioned it in his article:

Mi-Go is a creature that looks like a crustacean, and according to Lovecraft's description, the Mi-Go race comes from Eugene, Pluto. They have many abilities that transcend human technological forces, the most famous of which is the ability to take out the human brain alive and put it in a cylinder made of Eugene's idiosyncratic metal, the Lagh metal. So that it can be carried on an interstellar journey. Whether this exciting-sounding interstellar trek is harmless or not, and whether Mi-Go was malicious to humans, the story didn't tell us, but at the end of the story he left a skinned Mi-Go and cut off his hands. A pitiful human whose brain is placed in a metal tube. (85)

\subsubsection{Origin of Cthulhu Mythos}

As a young artificial myth, Cthulhu Mythos cannot be separated from the modern people's exploration of the unknown - it is the embodiment of people's uneasiness about this kind of exploration. Although human technology has so far been able to easily change nature, but universal space and endless new mysteries are still lingering, 
accompanied by new fears of the unknown. The world's most famous theoretical physicist, Stephen William Hawking, once warned humans to be hesitant about making contact with our extraterrestrial neighbors. He said that meeting an advanced civilization could be like Native Americans encountering Columbus. That did not turn out so well. So it is not yet known what kind of dangers lie hidden in the universe and what kind of crisis it will bring to the earth so far.

The active pursuit of aliens dates back to 1974 . The Arecibo Observatory sent Earth radio signals to a globular cluster called M13 in the constellation Cassiopeia, 25000 light-years from Earth. It contained a lot of basic information about the Earth, such as the solar system, the human DNA structure, resident characters and so on. The idea was to explore the behavior of other living things in the universe, but now it is being questioned - it is impossible to predict whether the existences of receiving information will bring disaster to the planet. To this day, people's exploration of the universe is still limited, the universe is full of fatal dangers everywhere. If you are not careful, you will die. The birth of Cthulhu Mythos reflected Lovecraft's own deep concern about the exploration of the universe. Almost all of the powerful and evil ancient gods and strange inhuman things in his story came from the deep universe. All in all, Lovecraft's concerns went beyond the context of the times, which was why people could not accept his work at that time. Kelabu mentioned in his article in Science Fiction World:

From today's point of view, the reason why Cthulhu Mythos was criticized by the public at that time was that it transcended the era of its existence and exceeded the reader's favorite taste: in an age when people still insisted on geocentric theory. Most of Lovecraft's works contain pessimistic and cynical feelings, which are incompatible with the values of enlightenment, romanticism and Christian humanism. In short, readers at the time preferred to see the hero's heroic adventures in outer space rather than scream at the inexplicable unknown. (84)
But with the birth of nuclear weapons, people are becoming more and more aware that technology is a double-edged sword, and no one knows whether the rapid development of technology will create a new sword of Damocles. Cthulhu Mythos suggest that the evil gods in the depths of the universe are equally alarming: whether the random exploration of the universe will lead to extinction by violating the powerful existence of inviolability. Therefore, this young artificial myth is not only an amazing imagination, but also a projection of the cosmic world under modern science.

\subsection{Comparison of the supernatural images and the images in Cthulhu Mythos}

Once Tong Qingbing had given a definition to the image:

"Image" is image, which ancient meaning is "ideographic image", is used to express some “abstract ideas and philosophies.” (230-231)

Now, it refers to "a special kind of expressive artistic image or literary image". Therefore, its most important feature is symbolism and philosophy, which turn the image into a "carrier of meaning." (233)

The images used in different types of novels are often different. There are also distinctive images in horror novels, which are constantly changing and expanding with the development of the times. However, the most typical images are supernatural images. Regulars in traditional horror novels, such as the ghost of Edgar Allan Poe's The Fall of the House of Usher and the headless knight in Washington Irving's The Legend of Sleepy Hollow, are the first sensory stimuli the author gives the reader in order to create an atmosphere to drive the plot. In turn, the reader is aware of the hints and fears hidden behind the daily taboos. According to Zhao Wei and Liu Yuping, it is easy to understand supernatural images:

All in all, supernatural images are directly related to the reader's sensory impact at the same time, and people are born with the "fear of the unknown". The introduction of it into the novel can make the reader have both physical and psychological terror. (88) 
Supernatural images are essentially people's exploration of the soul and the postmortem world, and fear of the unknown .On the one hand, with the development of the times and the progress of science, the phenomenon that could not be explained in the past has already been reasonably explained. The development of science is making the fear and uneasiness caused by ignorance disappear gradually. That is what Wang Fenning pointed in her paper: "In other words, the concept of ghosts comes from 'a kind of misperception and primitive thinking experience of one's own physiological phenomena and the surrounding world'." (123)

On the other hand, despite the development of science, people's fear of the unknown continues unabated. That is what Lovecraft had said:“"The oldest and strongest emotion of mankind is fear; and the oldest and strongest kind of fear is fear of the unknown." (Yao back cover)

What is emphasized in Cthulhu Mythos is a new kind of unknown thing. Readers can only see a corner of the unknown from the description of a few words, which is enough to make the readers realize the indescribable terror hidden behind. Unlike traditional supernatural images, Lovecraft's novels do not appear in images such as ghost or zombies, but are replaced by unheard of evil creatures, some of which do not even belong to Earth. Just knowing they exist had driven the characters crazy in the story. For example, Stephen Edwin King's The Mist, hidden in the fog of evil forces, people in face of this unknown force to fight back, can only come to an end in madness and fear. In Cthulhu Mythos, the fear of the unknown is constantly becoming fierce, and as the narrator in the story has a deeper understanding of the events in which he is located, he will have a deeper understanding of the hidden dangers in the depths of the universe. Further discover the insignificance and ignorance in the face of indescribable forces. How shallow the current understanding and knowledge of human beings are all displayed in front of the reader, causing the reader's surprise at the same time just let people feel cold behind.

In a word, the use of supernatural images shows that horror novels with the development of the times and the widening of the narrative field of the novel, the efforts in the text and the excavation of the inner secret world of contemporary people. The horror novel emphasizes that the reality is reflected by strange events. The weirder the story is, the stronger the reader's reaction can be, which makes the reader fall into a complicated plot and eventually fall into a horrific and creepy atmosphere. So people can see Cthulhu Mythos is the product of the development of the times, and the images it contains reflect the new concerns brought about by the new science and technology and advanced research progress under the background of the modern era. The combination of Lovecraft's concerns about the development of science and technology and the fear of human beings in the face of the unknown gives readers a whole new feeling.

\section{THE INFLUENCEOF CTHULHU MYTHOSON MODERN WESTERN SPINE-CHILLERS}

\subsection{The gruesome elements in modern western spine-chillers}

Due to the development of the times and the evolution of novel types, supernatural images have been far from meeting people's stimulation and fidelity to the requirements of horror novels, and have been proved to be the product of false fantasies has been unable to bring fear to people. Under this condition, the image of modern western horror novels has also undergone new changes and introduced new content. In order to find new images, the types of terror focus on the things that can be seen everywhere in daily life. At the same time, with the economic recovery of modern western society, people's pursuit of spiritual and material aspects has increased, which is the reason that so many people are pursuing fresh stimulation. They are not even satisfied with the simple written experience. Instead, it requires other senses, such as vision. This makes the industry in the consumer era have flocked to the market to form an industrial chain. Under the demand of external stimulation and internal creation, the creators of new terrorist works emerge in endlessly.

One of the classic writers, Stephen King, is a new generation of horror novelists who can change history. And Kang Shi gave the example in his essay:

Stephen King believes that traditional Gothic horror novels only focus on rendering the 
atmosphere of terror, resulting in the lack of the inner plot of the novel. The description of the characters' personality characteristics is not perfect, and a series of modern terrorism novels, such as The Shining, The Stand, Salem's Lot and so on, have been successfully created through the fusion of human films to express their skills and novels. (202)

Whether the hotel which gradually push people into crazy in The Shining, or the clown who bring childhood shadows to countless people in It, these images throw away impracticality and become so different from supernatural images. They have become something closely related to people's lives, which brings readers the fear of metaphors hidden in daily life.

In addition to novels, a large number of film and television programs and online games have begun to add gruesome elements to attract people's attention. Like Silent Hill, a horror game which was adapted into a movie and moved to the screen later, is still a classic in the hearts of countless people. There is an inner world in the game, where it will not only awaken the dark side of people's hearts, but also have unreasonable monsters that do not exist in real world. In fact, consciousness is the reason for the difference between the inner world and the real world. As a unique horror image, consciousness is actually the reaction of the characters' spiritual world. As Nietzsche said, 'when you stare into the abyss, the abyss gazes at you.'Sometimes people's fears of themselves are far greater than the stimuli of foreign objects.

Modern western horror film and television works also try to innovate something new, as a result, the wax figures in House of Wax have left a deep impression on many viewers. In addition, new animal images have been added. Such as in Jaws hidden in the water ferocious cunning white shark, as well as in Anaconda living in the dense forest python. In such works, people are often placed in isolation from the outside world, close to these animals with far more power than human beings to fight for a chance of survival. The selection of well-known animals as the protagonist of the enemy. These animals are either species that survived from prehistoric times, or have been influenced by human technology, for a variety of reasons.
This is not important. What is important is that these animal images can be seen everywhere and are closely related to people's lives. Because of this, the audience can touch the potential crisis in life, and then make the audience feel the fear of this unknown threat.

\subsection{Comparison of images in Cthulhu Mythos and modern western spine-chiller}

Although the new elements and images of terror introduced in modern western Spine-chillers are in full bloom, readers can still find out the inextricable links with the myth of Cthulhu. For example, Stephen Edwin King, the horror writer mentioned in the previous section, his most representative of which is the evil force in The Mist, which is helpless to even the military. It is clearly that the evil force directly uses the monster image from Cthulhu Mythos' story - The Void. The atmosphere of madness and despair in the novel sets off the smallness of human beings. In the face of this unknown and powerful force, most of what human beings do is futile. Such a similar situation is reminiscent of Lovecraft's works, such as the mysterious island in Call of Cthulhu and the disturbing underwater shrine in The Temple. In addition, many of Stephen Edwin King's works are influenced by Lovecraft, meanwhile, inherited the structural characteristics of cult fanatics, vague clues and obscure endings in Lovecraft's literature.

The unique style and characteristic mythological system of Cthulhu Mythos has attracted a large number of fans in modern times, whether it is film and television or game animation industry are deeply affected by it. Because Cthulhu Mythos works are always accompanied by detective behavior such as the protagonist's step-by-step excavation of the truth, the scripts for role-playing and desk-playing games adapted against the background of Cthulhu mythos are also dazzling. And "Steam", an online gaming platform that is now popular with young people, can also find many games that contain Cthulhu gruesome elements, and even have special Lovecraft tags to describe such games. More games, even if not labeled, involve Cthulhu gruesome elements. In the popular online game World of Warcraft can also find the relation of the terrorist elements of Cthulhu Mythos: Yogg Salon, Enzos and so on, which are based on Outer Gods of Cthulhu Mythos. They come from the universe to Azeroth in ancient times, 
enslaved and squeezed the natives and were eventually sealed by the Titan gods, part of which saluted the struggle between Great Old Ones and Outer God in the Cthulhu Mythos.

In modern western films and television works, the influence of Cthulhu gruesome elements is more intuitive, the best known is Captain David Jones in Pirates of the Caribbean, whose face is almost identical to Cthulhu's description. Moreover, there are a lot of films and television that salute and use the gruesome elements of Cthulhu, like the macrophage worm in Star War and the prequel to Alien: Prometheus. In the long horror drama Supernatural, there is also a small town written by Lovecraft: "Innsmouth," and Yog-Sothoth, one of the Great Old Ones in Cthulhu Mythos, also has an alias "Yogth" appeared in the play. There are also scenes of homage to Cthulhu Mythos: for example, one of the protagonists reads Cthulhu Mythos in the bedroom; and the book, The Haunter of the Dark, appears in the blood in another scene, which refers to one of the Nyarlathotep, ternary gods.

However, the original author Lovecraft himself describes more of the unknown horrors from the universe, which is why in many alien sci-fi films, people often see extraterrestrial creatures or monsters that draw on the horror elements of Cthulhu Mythos. The core of Lovecraft's terror is cosmology. He emphasizes that the limited mind of human beings cannot understand the nature of life and the truth of things. Because of the smallness of human beings, the universe is ruthless to human beings. He argued that any search for the mysterious unknown would lead to a disastrous outcome. The world of Cthulhu Mythos is a world that cannot be understood by the existing knowledge of human beings. What is really scary about it is that it is beyond the imagination of the unknown. From today's point of view, the reason why Cthulhu Mythos was criticized by the public at that time was that it transcended the era of its existence and exceeded the reader's favorite taste: in an age when people still insisted on the geocentric theory, Most of Lovecraft's works contain pessimistic and cynical feelings, which are incompatible with the values of enlightenment, romanticism and Christian humanism. In short, readers at the time preferred to see the hero's heroic adventures in outer space rather than scream at the inexplicable unknown. It is precisely because of scientific progress that people understand their ignorance, begin to face up to and appreciate the charm of Cthulhu Mythos, and bring this charm to their own creations.

\subsection{Summary of the gruesome elements in modern western spine-chillers}

Cthulhu Mythos has remarkable characteristics, as Massimo once mentioned:“Adjectival accumulation and emphasize the insufficient ability of words to depict the scene in order to transcend the observed object to achieve the description of the observed object." (Massimo 418)

It is different from the concepts of Greek mythology and Sumerian mythology. It is neither the imaginary spiritual destination of human beings nor the political means used to control the people. The gods of Cthulhu Mythos are the existence of evil which is difficult for human beings to understand or even call evil. The protagonists in Cthulhu Mythos system always take the familiar world as the starting point and expose the anomalies hidden under the ordinary appearance in the obscure clues until they find that the world is actually surrounded by distortion and madness. As Lovecraft himself said:

The mysteries end with the narrator discovering the existence of these beings though ancient forgotten knowledge found in some tomb, recorded incidences reported in various media and investigations, and the first hand encounter with said cosmic entity. As the story unfolds, the truth leads to the character's contemplation and admission of the hopeless plight of humanity which stands ignorant. (23)

The Cthulhu Mythos, an artificial myth full of incomprehensible unknown forces and unknown fears, has become more widely known and more easily accepted with the development of the Internet. It also makes it clear that terrorist works are not only blood and murder, but also broadens people's understanding of terrorist works. Joseph A. Lesny also provided his point of view about Lovecraft's works:

To Lovecraft, humanity is a smug and insignificant race that fails to contemplate the 
infinite void of chaos that surrounds the earth. From that void of cosmic space come creatures and entities of such power that humanity cannot contemplate the existence of such beings and risk being consumed by the madness brought from such a horrible truth.

The source of Lovecraft's Cthulhu Mythos is not based in the supernatural. There are no ghosts or fiends of the night that plague humanity with unholy evil. The wickedness of Lovecraft's creation is existential and cosmic.

Cthulhu Mythos, such a mythological system, which runs counter to humanitarianism, has an indescribable attraction in today's rapid development of science and technology and the Internet. It attracts creators to understand it and finally indulges in it. As a matter of fact, it has indeed greatly promoted the development of modern Spine-chillers, as evidenced by the endless stream of works honoring Cthulhu Mythos. The traditional Gothic horror novels only pay attention to the rendering of the horror atmosphere, ignoring the description of the plot and the shaping of the characters' character. Although there are also various problems in Cthulhu Mythos, however, it's strange and indescribable characteristics and reverie of unknown space coincide with people's aesthetic value. Whether it is well-known or unknown works, people can find traces of their influence by Cthulhu Mythos, and sigh at the greatness of the works left by Lovecraft.

\section{CONCLUSION}

There is no doubt that the current Cthulhu Mythos is a collective secondary myth. In the 19th century, people could not understand Lovecraft's worries about transcending the times, thinking that his description of the universe and mystery was just nonsense tortured by misfortune, guiding the development of science and technology and deepening people's understanding of the universe. It is only when we realize how small the human race is to the universe that we really realize the value of Cthulhu Mythos. Cthulhu Mythos shows Lovecraft's worries about the rapid development of science and technology, and his awareness of human limitations. Today his caution and worries are still not out of date. The more people improve their living standards in the progress of science and technology, the more they should remain vigilant, treat and use the double-edged sword of science cautiously. Although the creation time of Cthulhu Mythos is short, the research on Cthulhu Mythos is not thorough and comprehensive enough, and the existing data is not enough to study and analyze it as a model. But Cthulhu Mythos still really belongs to the 20th century, belongs to the myth of mankind, and it is open and infinite. Because more and more people are aware of the importance behind the Cthulhu Mythos, contemporary writers can better participate in its creation, and under the promotion of popular culture, which can be understood and accepted by more people. And at the same time, with the continuous development of the network, they can put in new substance, for the modern west and even the world's terrorist works into a new vitality.

\section{REFERENCES}

[1] Ke, L. B. Call of Cthulhu: Lovecraft and his artificial mythology[J]. Fantasy World, 2013(2): 83-89.

[2] Kang, S. The Comparison of the Origin and Evolution of Modern Eastern and Western Horror Novels[J]. Ability and Wisdom 2016(3): 202-203.

[3] Kong, X. Y. A Preliminary Study onCthulhu Mythos of the Horror Literature System[J]. Journal of Zaozhuang University2018(6): 79-84.

[4] Lin, Carter. Lovecraft: A Look Behind the Cthulhu Mythos. New York: Ballantine Books, 1972.

[5] Lovecraft H P. Supernatural horror in literature. New York: Dover Publication Inc, 1973.

[6] Lovecraft, H. P., Yao, X. H. translated. Cthulhu Mythos[M]. Zhejiang Publishing United Group Pub, 2008

[7] Lesny, Joseph A. "An Examination of Contributive Narrative: A look at the Lovecraft Circle and the Expansion of the Cthulhu Mythos. Research Integrity and Copyright Disclaimer". Diss.Purdue University, 2012. 
[8] Massimo, Berruti. "H. P.Lovecraft and the anatomy of the nothingness: The Cthulhu Mythos". Semiotica (150)2004, 418.

[9] Mark, Lowell. Lovecraft 's CTHULHU MYTHOS. The Explicator, 2004.

[10] Schachel, Robert C. "Textual Projections: The Emergence of a Postcolonial American Gothic”. Diss. University of Florida, 2006.

[11] Tong, Q. B. A Course in Literary Theory[ M]. Beijing: Higher Education Press Pub, 2008: 230-231.

[12]VanDenBos, Wesley. "Subverting a Mythology--Examining Joseph Campbell's Monomyth in the Fiction of H. P. Lovecraft". Diss. Liberty University, 2013

[13] Wang, F. L. The amorous feelings of Ghost and Fox: the Strange Tales of Liaozhai and Folk Culture[ M]. Harbin: Heilongjiang people's Publishing House Pub, 2003: 123.

[14]Xiong, X., Song, D. K. The Element of Terror in Cthulhu Mythos-- And on Lovecraft's Terror System[J]. Journal of Shenyang University (Social Science Edition), 2018, (2):224-232.

[15]Zhao, W., Liu, Y. P. A Brief Analysis of the Image and Its Implication in Horror Novels[J].Journal of Huaihua University, 2010, (3):87-88 